\title{
BIOMASS AND LEAF CHLOROPHYLL IN OITICICA SEEDLINGS UNDER WATER SALINITY IRRIGATON AND ORGANIC COMPOUND ADDITION
}

\author{
Alian Cássio Pereira Cavalcante ${ }^{1}$, Manoel Alexandre Diniz Neto², Lourival Ferreira Cavalcante ${ }^{3}$, Antônio \\ Gustavo de Luna Souto ${ }^{4 *}$, Adailza Guilherme Cavalcante ${ }^{5}$, Belísia Lúcia Moreira Toscano Diniz ${ }^{6}$ \\ ${ }^{1}$ Universidade Federal de Viçosa, Programa de Pós-Graduação em Fitotecnia, Viçosa, Minas Gerais, Brasil - e-mail: \\ cassio.alian216@gmail.com \\ ${ }^{2}$ Universidade Federal da Paraíba, Programa de Pós-Graduação em Ciências Agrárias (Agroecologia), Bananeiras, Paraíba, Brasil - email: \\ diniznetto@gmail.com \\ ${ }^{3}$ Universidade Federal da Paraíba, Programa de Pós-Graduação em Agronomia, Areia, Paraíba, Brasil - email: lofeca1946@yahoo.com.br \\ ${ }^{4 *}$ Universidade Federal da Paraíba, Programa de Pós-Graduação em Agronomia, Areia, Paraíba, Brasil - e-mail: gusluso @ hotmail.com \\ ${ }^{5}$ Universidade Estadual Paulista Júlio de Mesquita Filho, Programa de Pós-Graduaçãoem Agronomia (Produção Vegetal), Jaboticabal, São \\ Paulo, Brasil - e-mail: adailzacavalcante@gmail.com \\ ${ }^{62}$ Universidade Federal da Paraíba, Programa de Pós-Graduação em Ciências Agrárias (Agroecologia), Bananeiras, Paraíba, Brasil - email: \\ belisia.diniz@gmail.com
}

Received for publication on 28/05/2018 - Accepted for publication on: 20/11/2019

\begin{abstract}
Resumo
Biomassa e clorofila foliar em mudas de oiticica sob salinidade da água e composto orgânico. As áreas agrícolas comprometidas por sais, das regiões semiáridas do Nordeste brasileiro, têm aumentado devido à utilização de água com elevada concentração salina como único suprimento hídrico disponível às plantas, prejudicando a qualidade das mudas e o rendimento produtivo das culturas. Uma das formas de amenizar os efeitos prejudiciais dos sais é o uso de composto orgânico no substrato como forma de atenuar a ação da salinidade da água e do solo na formação de biomassa e atividade clorofilática em mudas e plantas adultas de espécies silvícolas, inclusive de oiticica. Nesse sentindo, objetivou-se avaliar os efeitos da salinidade da água de irrigação e proporções de composto orgânico, obtido pela fermentação de partes vegetais de mamoneira (Ricinus communis) e esterco bovino no acúmulo de biomassa e índices de clorofila em mudas de oiticica. $\mathrm{O}$ experimento foi desenvolvido no esquema fatorial $4 \times 2$, em blocos casualizados, com cinco repetições e duas mudas por parcela, relativo as proporções de composto orgânico - $\mathrm{C}$ e solo - S (0C:1S, 1C:1S, 2C:1S, 3C:1S) e irrigação das mudas com água não salina $\left(0,5 \mathrm{dS} \mathrm{m}^{-1}\right)$ e salina $\left(4,5 \mathrm{dS} \mathrm{m}^{-1}\right)$. O aumento de composto orgânico no substrato na proporção em relação ao solo de 3:1 superou em $42,9 \%$ a biomassa da parte aérea das mudas de oiticica irrigadas com água salina. Pelos resultados, o composto orgânico mitiga, mas não elimina os efeitos prejudiciais da salinidade da água de irrigação sobre a formação de biomassa e os índices clorofiláticos das mudas.
\end{abstract}

Palavras-chave: Licania rigida Benth, estresse salino, insumo orgânico, fitomassa, pigmentos clorofiláticos.

\begin{abstract}
Salt-compromised agricultural areas in the semi-arid regions of the Brazilian Northeast, have increased due to the use of water with high saline concentration as the only water supply available to plants, damaging the quality of the seedlings and the productive yield of the crops. One way to alleviate the detrimental effects of salts is the addition of organic compound to the substrate as a way to attenuate the action of water and soil salinity on biomass formation and chlorophyllactic activity in seedlings and adult plants of forest species, including Licania rigida Benth, the Oiticica. In view of this issue, the objective of this study was to evaluate the effects of water salinity irrigation and of the addition of an organic compound obtained by fermentation of castor bean (Ricinus communis) and cattle manure on biomass accumulation and chlorophyll indices in Oiticica seedlings. The experiment was carried out in a $4 \times 2$ factorial scheme in randomized blocks, with five replications and two seedlings per plot, relative to the proportions of organic compost - $\mathrm{C}$ and soil - S (0C: 1S, 1C: $1 \mathrm{~S}, 2 \mathrm{C}$ : $1 \mathrm{~S}$, $3 \mathrm{C}: 1 \mathrm{~S})$ and irrigation of the seedlings with non-saline $\left(0.5 \mathrm{dS} \mathrm{m}^{-1}\right)$ and saline $\left(4.5 \mathrm{dS} \mathrm{m}^{-1}\right)$ water. The increase of organic compound in the substrate in proportion to the soil of 3: 1 surpassed by $42.9 \%$ the biomass of the aerial part of the Oiticica seedlings irrigated with saline water. The results indicate that the organic compound mitigates, though does not eliminate, the detrimental effects of water salinity irrigation on the biomass formation and chlorophyllactic indexes of the seedlings.

Keywords: Licania rigida Benth, saline stress, organic input, phytomass, chlorophyllactic pigments.
\end{abstract}

\section{INTRODUCTION}

Soil salinity has increased in agricultural areas of arid and semi-arid regions of the world such as the Brazilian Northeast. This rise has been mainly due to less than adequate irrigation management and high concentrations of salts in the waters used in agriculture (GORJI et al., 2017). Water salinity results from the natural

FLORESTA, Curitiba, PR, v. 50, n. 2, p. 1161 - 1170, abr/jun 2020.

Cavalcante, A. C. P. et.al.

ISSN eletrônico 1982-4688 
process of weathering of primary minerals concentrated in elements essential to vegetation, mainly calcium, magnesium, and potassium, in addition to those rich in sodium (RIBEIRO et al., 2016). Sodium salts make up the highest concentration of the cations; among anions, chloride salts are predominant, with sodium chloride being the most frequent - and in a greater percentage in soils and waters of tropical and subtropical regions. To a lesser extent, bicarbonate, carbonate, and sulfate salts that are solubilized in irrigation water also contribute to damage plant growth, seedling formation, and plant yield (MUNNS; GILLIHAM, 2015).

The prospect of an increasing world population density leads to the need to include salt-compromised areas and the use of high-salinity concentrated waters (even simultaneously) in the food production chain and in the production of energy resources. In arid and semi-arid areas of the world, such as Northeastern Brazil, water resources have salt in concentrations not tolerated by the seedlings of food, non-food, and energy-potential species of plant such as Licania rigida Benth, the Oiticica (SOUZA et al., 2014; CAVALCANTE et al., 2016).

Oiticica is an endemic species of the semiarid region of Northeastern Brazil and, in recent years, has gained economic significance due to the extraction of oil from its seeds, which is used in biofuel production and in the paint and varnish industry (QUEIROGA et al., 2016). As for its threshold salinity, Oiticica behaves as a salt-sensitive species, whose growth, aerial biomass accumulation, and synthesis of photosynthetic pigments are inhibited when the seedlings are irrigated with water with electrical conductivity levels above $0,5 \mathrm{dS} \mathrm{m}^{-1}$ (DINIZ NETO et al., 2014; CAVALCANTE et al., 2016).

Salt-related stress in plants is evaluated by the osmotic action, by the complex mixture of salts in the water and/or in the soil solution, and by the specific damages caused by some cationic species, such as sodium and magnesium, and some anionic species, such as chloride, boron, and nitrate. The osmotic effect, caused by an increase of the electrical conductivity level, reduces the energy status of the soil water in relation to the plants; the saline effects study the concentrations and compositions of salts in the water and in the soil that cause nutritional imbalances in the plants (SYVERTSEN; GARCIA-SANCHEZ, 2014); specific salinity, as the name implies, studies the effects on the plants of some components of water and soil salinity, such as sodium, chloride, boron, and nitrate (KAYA et al., 2010; MUNNS; GILLIHAM, 2015).

Increased salinity causes growth inhibition in the formation of biomass in response to a decrease in the absorption of water, whose incremented concentration enhances plants' absorption of saline nutrients (TURAN et al., 2010; SA et al., 2013; SYVERTSEN; GARCIA-SANCHEZ, 2014). In addition to such damage, accumulation of salts in the leaf tissues increases the activity of chlorophyllase, a proteolytic enzyme that promotes the degradation of chlorophyll and compromises the photochemical phase of photosynthesis and the quality of seedlings (SANTOS, 2004; CAVALCANTE et al., 2011; SOUTO et al., 2015).

Among the alternatives to mitigate salt-related damage in plants is the addition of animal or vegetable organic compound to the substrate (KHALED et al., 2011; LOPES et al., 2017). Organic inputs reduce the exchangeable sodium percentage (ESP), improve soil structural properties, supply essential nutrients, and also act in the osmoregulation of plants in saline medium (MIRANDA et al., 2011; FREIRE et al., 2013). According to Cavalcante et al. (2016), the organic compound based on vegetable remains of castor bean (Ricinus communis) attenuates the depressive action of salts in the accumulation of biomass and chlorophyll production in seedlings.

However, there is a dearth of studies specifically addressing the adequate proportion between organic compound and soil in the production of substrate when the only source of water contains high levels of salts. Therefore, the present work aimed to evaluate (i) the effects of different proportions of organic compound and soil in the substrate irrigated with water of increasing salinity in the formation of biomass and (ii) chlorophyll index during the formation of Oiticica seedlings.

\section{MATERIALS AND METHODS}

From February to May 2014, an experiment was conducted in a protected environment at the Center for Human, Social, and Agrarian Sciences (CCHSA) at the Federal University of Paraíba, in the city of Bananeiras, Paraíba, Brazil. The municipality is located at latitude of $6^{\circ} 46^{\prime} 00^{\prime}$ ' $\mathrm{S}$ and at a longitude of $35^{\circ} 38^{\prime} 00^{\prime}$ ' $\mathrm{W}$ according to the Greenwich meridian, at an altitude of $552 \mathrm{~m}$. The climate of the region, according to the Köppen classification, is of the 'As' type (tropical wet), hot and humid (ALVARES et al., 2013). The rainy season is concentrated between the months of April and August whereas the drought period is between September and December, with average annual temperature of $25^{\circ} \mathrm{C}$ and relative humidity of $65 \%$.

The experiment was conducted in a $4 \times 2$ factorial scheme, in randomized blocks, with five replications and two seedlings per plot. The sources of variation corresponded to four proportions of organic compound - C originated via composting of vegetable remains of castor bean and soil - S (0C: 1S, 1C: 1S, 2C: 1S, 3C: 1S) contained in soil irrigated with non-saline $\left(0.5 \mathrm{dS} \mathrm{m}^{-1}\right)$ and saline water $\left(4.5 \mathrm{dS} \mathrm{m}^{-1}\right)$. The Oiticica seeds were collected in the municipality of Catolé do Rocha, Paraíba, Brazil, from mother plants with no signs of physical 
injury or disease or pest symptoms. After collection, the seeds were packed in paper bags duly identified with place and date of collection and name of the responsible technician.

The substrate used in the experiment came from soil collected at $0.20-0.40 \mathrm{~m}$ and classified as Yellow Dystrophic Latosol, according to the Brazilian Soil Classification System - SiBCS (EMBRAPA, 2013). The organic compound used in the substrate was obtained by composting vegetative remains of the aerial parts of crushed castor bean (stem, branches, and leaves) in layers interspersed with 4:1 tanned bovine manure, that is, a layer with a thickness of $0,20 \mathrm{~m}$ of vegetative parts of castor bean and $0.05 \mathrm{~m}$ of bovine manure. The pile with the material (vegetable remains + bovine manure) was $1.0 \mathrm{~m}$ wide $\times 1.5 \mathrm{~m}$ high $\times 5.0 \mathrm{~m}$ long and revolved biweekly for 90 days, when the compound was uniformly colored and decomposed to be used as a substrate. Soon after, samples of soil and organic compound were collected to perform the chemical characterization (EMBRAPA, 2017), according to data presented in Table 1.

Table 1. Chemical characterization of soil and organic compound based on castor bean remains used as substrate Tabela 1. Caracterização química do solo e do composto orgânico à base de restos vegetais de mamoneira utilizados como substrato

\begin{tabular}{|c|c|c|}
\hline Chemical characterization & Soil & Organic compound \\
\hline $\mathrm{pH}\left(\mathrm{H}_{2} \mathrm{O}\right)$ & 5.7 & 8.2 \\
\hline Phosphorus (mg dm ${ }^{-3}$ ) & 19.1 & 921.0 \\
\hline Potassium $\left(\mathrm{cmol}_{\mathrm{c}} \mathrm{dm}^{-3}\right)$ & 0.3 & 12.3 \\
\hline Calcium $\left(\mathrm{cmol}_{\mathrm{c}} \mathrm{dm}^{-3}\right)$ & 4.4 & 14.1 \\
\hline Magnesium $\left(\mathrm{cmol}_{\mathrm{c}} \mathrm{dm}^{-3}\right)$ & 0.4 & 4.2 \\
\hline Sodium $\left(\mathrm{cmol}_{\mathrm{c}} \mathrm{dm}^{-3}\right)$ & 0.1 & 1.5 \\
\hline Potential acidity $\left(\mathrm{cmol}_{\mathrm{c}} \mathrm{dm}^{-3}\right)$ & 0.2 & 0.8 \\
\hline $\begin{array}{l}\text { Exchangeable aluminum }\left(\mathrm{cmol}_{\mathrm{c}}\right. \\
\left.\mathrm{dm}^{-3}\right)\end{array}$ & 0.0 & 0.0 \\
\hline $\mathrm{SB}\left(\mathrm{cmol}_{c} \mathrm{dm}^{-3}\right)$ & 5.2 & - \\
\hline CTC $\left(\mathrm{cmol}_{\mathrm{c}} \mathrm{dm}^{-3}\right)$ & 5.4 & - \\
\hline $\mathrm{V}(\%)$ & 96.3 & - \\
\hline Organic matter $\left(\mathrm{g} \mathrm{kg}^{-1}\right)$ & 17.9 & 259.0 \\
\hline Organic carbon $\left(\mathrm{g} \mathrm{kg}^{-1}\right)$ & 10.8 & 150.3 \\
\hline Nitrogen $\left(\mathrm{g} \mathrm{kg}^{-1}\right)$ & 0.6 & 9.4 \\
\hline $\mathrm{C}: \mathrm{N}$ ratio & 18: 1 & $16: 1$ \\
\hline
\end{tabular}

$\mathrm{pH}=$ hydrogen potential; Phosphorus $(\mathrm{P})=$ extractor - Melich-1; Potassium $\left(\mathrm{K}^{+}\right)=$extractor - Melich-1; Calcium $\left(\mathrm{Ca}{ }^{2+}\right)=$ extractor $-\mathrm{KCl} 1$ mol / L; Magnesium $\left(\mathrm{Mg}^{2+}\right)=$ extractor $-\mathrm{KCl} 1 \mathrm{~mol} / \mathrm{L}$; Sodium $\left(\mathrm{Na}^{+}\right)=$extractor $-\mathrm{KCl} 1 \mathrm{~mol} / \mathrm{L}^{2} \mathrm{Hydrogen}+\mathrm{Aluminum}\left(\mathrm{Al}{ }^{3+}+\mathrm{H}^{+}\right)=$ extractor - Calcium acetate $0.5 \mathrm{~mol} / \mathrm{L}$; Exchangeable aluminum $\left(\mathrm{Al}^{3+}\right)=$ extractor - Calcium acetate $0.5 \mathrm{~mol} / \mathrm{L} ; \mathrm{Sum}$ of bases $(\mathrm{SB})=\left(\mathrm{Ca}{ }^{2+}\right.$ $\left.+\mathrm{Mg}^{2+}+\mathrm{K}^{+}+\mathrm{Na}^{+}\right)$; Cation exchange capacity $(\mathrm{CTC})=\left(\mathrm{SB}+\left[\mathrm{Al}^{3+}+\mathrm{H}^{+}\right]\right) ;$Base saturation $(\mathrm{V})=([\mathrm{SB} / \mathrm{CTC}] \times 100) ;$ Organic matter $(\mathrm{MO})$ $=$ Walkley-Black method.

The experimental unit was represented by an Oiticica plant packed in a polyethylene plastic bag with a volume capacity of three liters and dimensions of $0.20 \times 0.30 \mathrm{~m}$. In each polyethylene bag, three seed of Oiticica were sown without any physical defect and with good physiological and sanitary quality. Seedling emergence started on the 20th day after sowing (DAS) and stabilized on the 30th DAS. On the 10th day after emergence (DAE), two seedlings were thinned, leaving the most vigorous by a polyethylene bag. The proportions of organic compost (C) and soil (S) in each treatment were: 0C: 1S, 1C: 1S, 2C: 1S and 3C: 1S, respectively.

Non-saline water $\left(0.5 \mathrm{dS} \mathrm{m}^{-1}\right)$ came from the municipality of Bananeiras, Paraíba, Brazil and saline water $\left(4.5 \mathrm{dS} \mathrm{m}^{-1}\right)$ was obtained by diluting soluble sodium chloride salts $(\mathrm{NaCl})$ non-iodized with $92 \%$ purity in nonsaline water $\left(0.5 \mathrm{dS} \mathrm{m}^{-1}\right)$, until the desired value was measured using a portable digital $\mathrm{CD}-860$ conductivimeter . The irrigations, during the conduction of the experiment, were done manually through the weighing method, supplying, every $24 \mathrm{~h}$, the volume of water evapotranspirated in each treatment, in order to raise the humidity level of each treatment to the level field capacity. 
The readings of the leaf indexes of chlorophyll $a, b$ and total, on the fourth leaf of the seedlings of occlusion, were made at 60 days after sowing (DAS), with a portable chlorophyll meter ClorofiLOG model CFL1030. Through the ratio between the chlorophyll $a$ and $b$ index, the chlorophyll $a / b$ ratio was determined. In the same period, the seedlings were collected, separated into aerial and root parts and placed in paper bags properly identified with the treatment, part of the collected plant and the person responsible for the sample. Then, they were taken to an air oven at a constant temperature of $65^{\circ} \mathrm{C}$ for $72 \mathrm{~h}$, a period for the samples to reach constant mass. The aerial and root biomass were measured using a semi-analytical balance $(p<0.01 \mathrm{~g})$. The data were subjected to analysis of variance by the $\mathrm{F}$ test at $5 \%$ probability and the averages related to water salinity were compared by the ' $F$ ' test, which is conclusive for values between two factors and those referring to the proportions of the organic compound in the substrate were compared by the Tukey test at $5 \%$ probability. The mean standard deviation of each variable was determined using the Excel 2010 version program and for data analysis, the statistical software SISVAR version 5.6 was used (FERREIRA, 2014).

\section{RESULTS}

According to the analysis of variance (Table 2), the interaction of salinity of water $\times$ proportion of organic compound in the substrate significantly influenced the dry mass of the aerial part and the total chlorophyll index of the seedlings. The chlorophyll indexes $a$ and $b$ responded in isolation to the effects of irrigation with saline water and the proportions of organic compost in the substrate. The relationship between the dry mass of the aerial part and the root was influenced by the salinity of the water, while the dry mass of the root and the relationship between the chlorophyll indexes $a$ and $b$ responded to the addition of organic compost.

Table 2. Summary of analysis of variance, by the mean square, referring to the dry mass of the aerial part (DMAP), root dry mass (RDM), dry mass of the aerial part and root dry mass (DMAP/RDM), chlorophyll a (CL $a$ ), chlorophyll b $(\mathrm{Cl} b)$ indices, chlorophyll $a / b$ ratio $(\mathrm{Cl} a / \mathrm{Cl} b)$ and total chlorophyll index $(\mathrm{Cl} t)$ in seedlings produced on the substrate with organic compound $(\mathrm{C})$ and irrigated with saline water $(\mathrm{S})$

Tabela 2. Resumo de análise de variância, pelo quadrado médio, referentes às variáveis massa seca da parte aérea (MSPA), massa seca das raízes (MSR), relação massa seca da parte aérea e massa seca das raízes (MSPA/MSR), índices de clorofila a $(\mathrm{CL} a)$, clorofila b $(\mathrm{Cl} b)$, relação clorofila $a / b(\mathrm{Cl} a / \mathrm{Cl} b)$ e índice de clorofila total $(\mathrm{Cl} t) \mathrm{em}$ mudas de oiticica produzidas no substrato com composto orgânico $(C)$ e irrigadas com água salina $(\mathrm{S})$

\begin{tabular}{|c|c|c|c|c|c|c|c|c|}
\hline SV & DF & \multicolumn{7}{|c|}{ Medium Square } \\
\hline & & DMAP & DRM & $\begin{array}{c}\text { DMAP/DR } \\
\mathrm{M}\end{array}$ & $\mathrm{Cla}$ & $\mathrm{Cl} b$ & $\mathrm{Cla} / \mathrm{Cl} b$ & $\mathrm{CLt}$ \\
\hline Blocks & 4 & $3,68^{\mathrm{ns}}$ & $1,96^{\mathrm{ns}}$ & $0,27^{\mathrm{ns}}$ & $2,12^{\mathrm{ns}}$ & $0,03^{\mathrm{ns}}$ & $0,12^{\mathrm{ns}}$ & $1,91^{\mathrm{ns}}$ \\
\hline Salt (S) & 1 & $29,90 * *$ & $0,02^{\mathrm{ns}}$ & $3,60 * *$ & $\begin{array}{c}302,50 * \\
*\end{array}$ & $36,10 *$ & $0,40^{\mathrm{ns}}$ & $403,22 * *$ \\
\hline Com (C) & 3 & $5,50^{\mathrm{ns}}$ & $4,62 * *$ & $0,70^{\mathrm{ns}}$ & $285,76^{*}$ & $4,70 * *$ & $1,86^{*}$ & $428,09 * *$ \\
\hline $\mathbf{S} \times \mathbf{C}$ & 3 & $8,30 *$ & $0,95^{\mathrm{ns}}$ & $0,86^{\mathrm{ns}}$ & $7,76^{\mathrm{ns}}$ & $0,16^{\mathrm{ns}}$ & $0,13^{\mathrm{ns}}$ & $18,22^{*}$ \\
\hline Residue & 28 & 2,01 & 0,76 & 0,34 & 5,78 & $0,39^{\mathrm{ns}}$ & 0,46 & 4,78 \\
\hline Total & 39 & & & & & & & \\
\hline Rate & & 7,25 & 3,72 & 2,15 & 23,75 & 6,05 & 4,00 & 29,17 \\
\hline smd (S) & & 0,91 & 0,56 & 0,38 & 1,55 & 0,40 & 0,44 & 1,41 \\
\hline smd (C) & & 1,73 & 1,06 & 0,18 & 2,93 & 0,76 & 0,80 & 2,67 \\
\hline $\begin{array}{l}\text { smd } \\
(\mathrm{S} / \mathrm{C})\end{array}$ & & 1,50 & 2,45 & 1,01 & 4,15 & 1,08 & 1,18 & 3,77 \\
\hline $\begin{array}{c}\text { smd } \\
(\mathbf{C} / \mathrm{S}) \\
\end{array}$ & & 1,13 & 1,83 & 0,76 & 3,11 & 0,81 & 0,88 & 2,83 \\
\hline $\mathrm{CV}(\%)$ & & 19,60 & 23,40 & 27,38 & 10,10 & 10,40 & 17,10 & 7,50 \\
\hline
\end{tabular}

$\mathrm{SV}=$ source of variation; $\mathrm{DF}=$ Degree of freedom; smd = significant mean deviation; ns, $*$ and $* *=$ not significant, significant at $5 \%$ and $1 \%$, respectively.

The dry mass of the aerial part of the Oiticica seedlings was increased with the proportions of organic compost in the substrate, regardless of irrigation with non-saline or saline water (Figure 1). In seedlings irrigated 
with water of $0.5 \mathrm{dS} \mathrm{m}{ }^{-1}$, the 1:1 ratio of organic compost and soil contributed to the greater accumulation of dry mass of the aerial part, presenting a superiority of $30 \%$ in comparison to the treatment seedlings with only soil; higher proportions of organic input reduced the accumulation of dry matter. On the other hand, the increase in the proportion of organic input in the 3: 1 substrate inhibited the harmful action of salts in irrigation water (4.5 dS m 1) under the biomass of the aerial part of the Oiticica seedlings, with an increase $42.9 \%$ compared to seedlings grown on the substrate containing only soil.

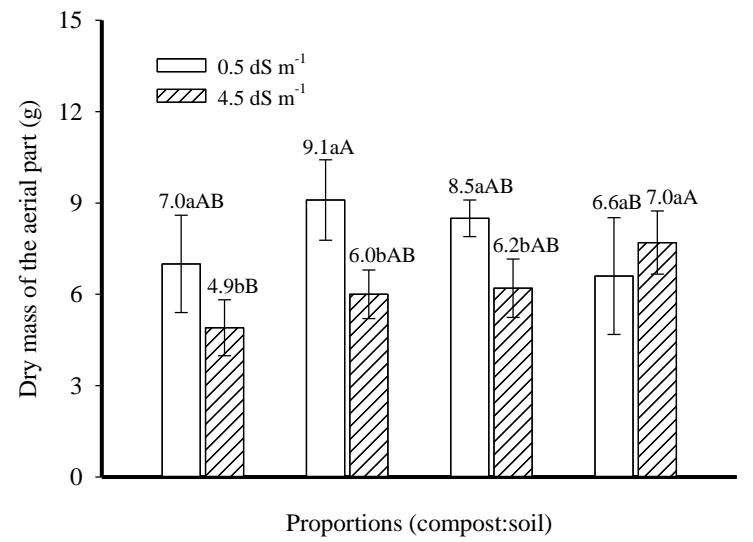

Figure 1. Dry mass of the aerial part in seedlings of Oiticica, irrigated with non-saline water $\left(0.5 \mathrm{dS} \mathrm{m}-^{-1}\right)$ and saline $\left(4.5 \mathrm{dS} \mathrm{m}^{-1}\right)$, in the substrate with proportions of organic compost and soil.

Figura 1. Massa seca da parte aérea em mudas de oiticica, irrigadas com água não salina $\left(0,5 \mathrm{dS} \mathrm{m}^{-1}\right)$ e salina $(4,5$ $\mathrm{dS} \mathrm{m} \mathrm{m}^{-1}$ ), no substrato com proporções de composto orgânico e solo.

The organic compost provided the conditions for the greatest accumulation of dry root biomass of the seedlings of occlusion (Figure 2). The increase in the proportion of organic input from 0 to 3 parts in the substrate stimulated the formation of root mass of seedlings from $2.50 \mathrm{~g}$ to $4.15 \mathrm{~g}$, which represents an increase of $66 \%$. However, there was no statistical difference between the proportions of 2: 1 and 3: 1 in the evaluated variable, with values of 3.80 and $4.15 \mathrm{~g}$, respectively.

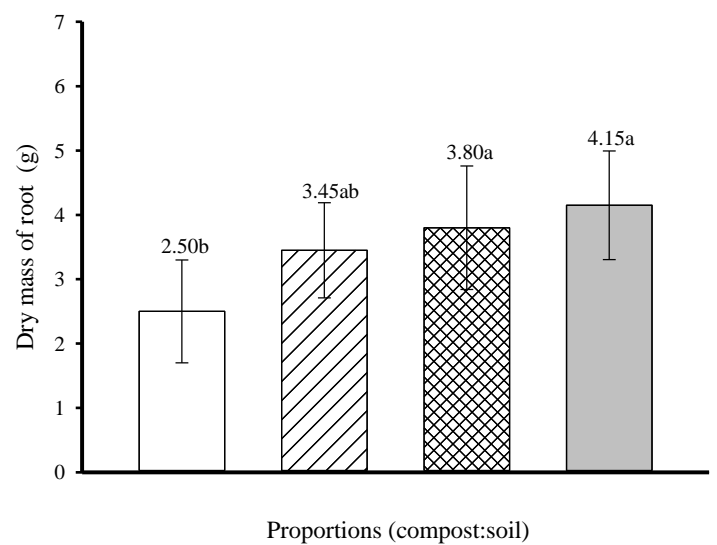

Figure 2. Dry mass of root in Oiticica seedlings grown on substrate with proportions of organic compost and soil. Figura 2. Massa seca da raiz em mudas de oiticica cultivadas em substrato com proporções de composto orgânico e solo.

The dry mass ratio of the aerial and root parts was reduced by irrigating the seedlings with saline water (Figure 3). The increase in water conductivity from 0.5 to $4.5 \mathrm{dS} \mathrm{m}{ }^{-1}$ reduced the DMAP/DMR ratio from 2.33 to 1.89 , that is, in the seedlings irrigated with saline water, the aerial part was more affected than the root system. 


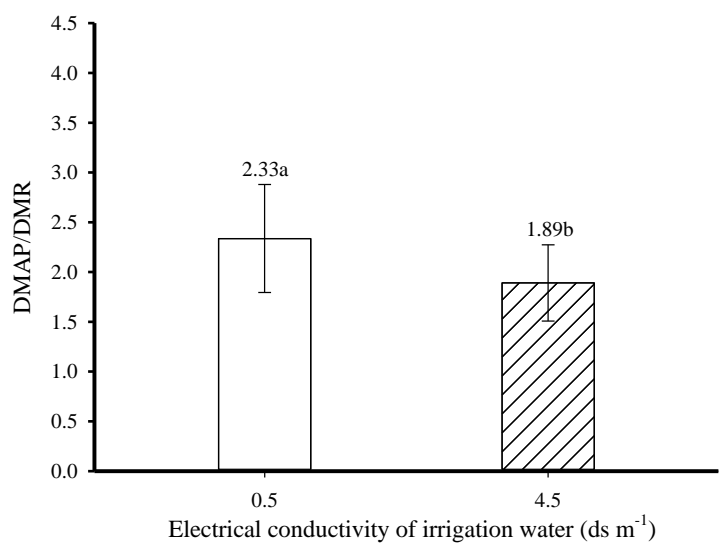

Figure 3. Dry mass ratio of aerial part and root dry mass in Oiticica seedlings irrigated with non-saline and saline water.

Figura 3. Relação massa seca da parte aérea e massa seca da raiz em mudas de oiticica irrigadas com água não salina e salina.

The salinity of the irrigation water inhibited the production of photosynthetic pigments from the seedlings of Oiticica, measured through the chlorophyll indexes $a$ and $b$ (Figures 4A and 4C). The increase of electrical conductivity of water 0.5 to $4.5 \mathrm{dS} \mathrm{m}{ }^{-1}$ reduced chlorophyll content at 26.42 to 20.92 and the chlorophyll $b$ of 6.95 to 5.11 , corresponding to $\mathrm{s}$ losses of 20.8 and $26.5 \%$, respectively. On the other hand, the addition of organic compost to the substrate, as seen in Figures 4B and 4D, increased the chlorophyll indexes $a$ and $b$ of the leaves of octave, compared to the seedlings of the treatments without the organic input. The proportions of 1: 1 and 2: 1 of organic compost and soil, despite showing the greatest results, did not differ, with the values of 29.03 and 27.19 for the chlorophyll ae index of 6.89 and 6,35 for chlorophyll index b, respectively.
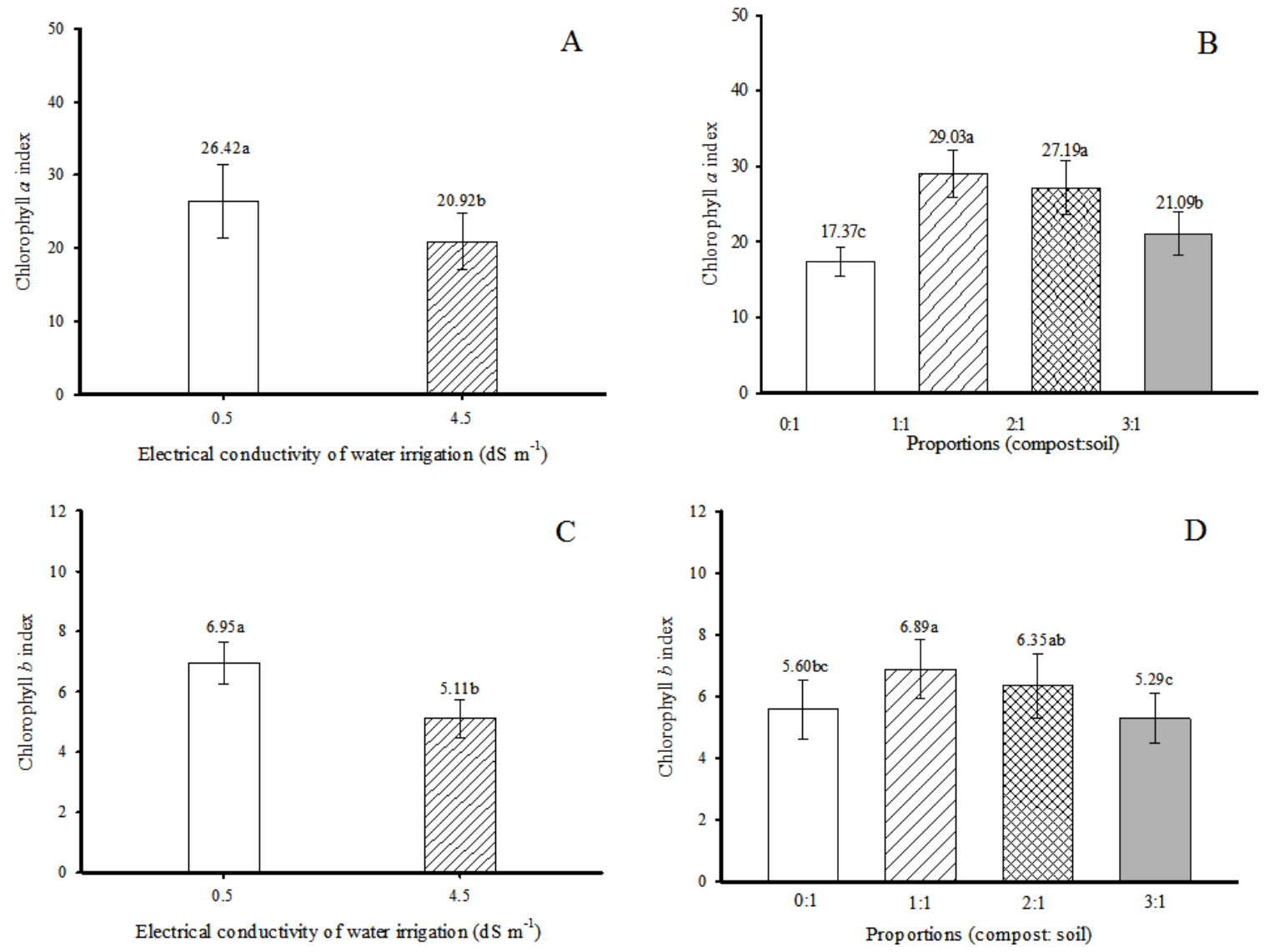

FLORESTA, Curitiba, PR, v. 50, n. 2, p. 1161 - 1170, abr/jun 2020 
Figure 4. Chlorophyll $a$ and $b$ in seedlings irrigated with non-saline and saline water (A and C) and in the substrate with proportions of organic compost and soil (B and D).

Figura 4. Clorofila $a$ e $b$ em mudas irrigadas com água não salina e salina (A e C) e no substrato com proporções de composto orgânico e solo (B e D).

The relation between the chlorophyll $a / b$ values of Oiticica seedlings was high with the application of organic compost on the substrate (Figure 5). The plants grown on the substrate in the ratio 2: 1 of organic soil and compound exhibited the largest value of $\mathrm{Cl} t o / \mathrm{Cl} b 4,33$, statistically overcoming s seedlings developed in the soil without organic compound, without significant differences between the proportions 1:1 and 3:1. This shows that in relation to the seedlings, the addition of organic matter in the substrate contributes to the increase in growth and chlorophyll index $a$ in relation to chlorophyll $b$.

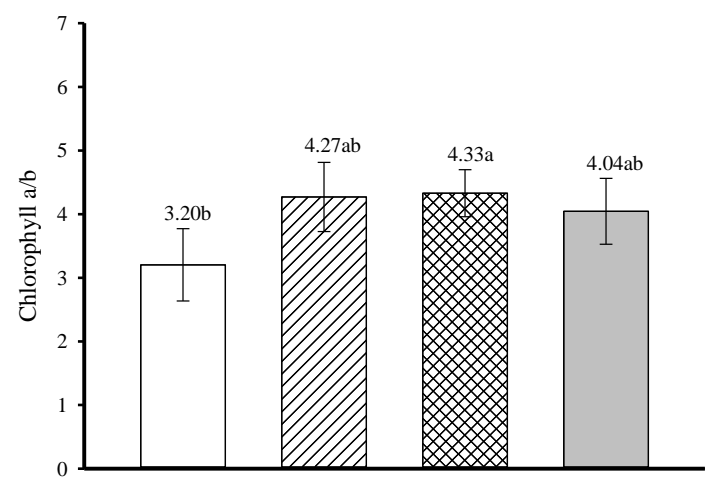

Proportion (compost:soil)

Figure 5. Relationship of chlorophyll $a / b$ in Oiticica seedlings cultivated on substrate with proportions of organic compost and soil.

Figura 5. Relação clorofila $a / b$ em mudas de oiticica cultivadas em substrato com proporções de composto orgânico e solo

The total index of total chlorophyll was high with the application of organic compost in relation to the substrate seedlings without the respective input, with statistical differences up to the 2:1 ratio of soil and organic compost, regardless of irrigation with non-saline or saline water. (Figure 6). The highest $\mathrm{Cl} t$ values were found in the 1C substrate seedlings: $1 \mathrm{~S}\left(39.96-0.5 \mathrm{dS} \mathrm{m}^{-1}\right.$ and $\left.31.88-4.5 \mathrm{dS} \mathrm{m}{ }^{-1}\right)$; although they do not differ statistically from the results of the $2 \mathrm{C}$ : $1 \mathrm{~S}$ ratio, but have always been numerically superior in seedlings irrigated with nonsaline water, showing that the organic compound attenuates the harmful effects of salinity. When relating the values, between the substrates $1 \mathrm{C}: 1 \mathrm{~S}$ and $0 \mathrm{C}$ : $1 \mathrm{~S}$, it appears that the organic input increased the leaf index of total chlorophyll, at least by $57 \%$ in seedlings irrigated with non-saline and saline water, respectively.

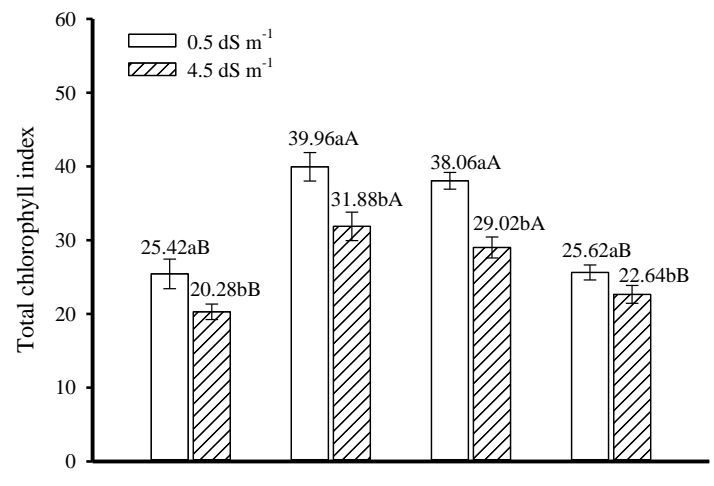

Proportions (compost:soil)

Figure 6. Total chlorophyll in Oiticica seedlings irrigated with non-saline water $\left(0.5 \mathrm{dS} \mathrm{m}^{-1}\right)$ and saline $(4.5 \mathrm{dS} \mathrm{m}$ ${ }^{-1}$ ) in the substrate with proportions of organic compost and soil.

Figura 6. Clorofila total em mudas de oiticica irrigadas com água não salina $\left(0,5 \mathrm{dS} \mathrm{m} \mathrm{m}^{-1}\right)$ e salina $\left(4,5 \mathrm{dS} \mathrm{m}^{-1}\right)$ no substrato com proporções de composto orgânico e solo. 


\section{DISCUSSION}

The statistical behavior of the data (Table 2) is in agreement with seedlings with those obtained by Diniz Neto et al. (2014), when reporting that plant biomass and total chlorophyll index were influenced by irrigation with water of up to $6.0 \mathrm{dS} \mathrm{m}{ }^{-1}$ in the substrate with bovine biofertilizer. On the other hand, Cavalcante et al. (2016) observed that the biomass accumulation variables and the chlorophyllate indexes of the Oiticica seedlings were not influenced by irrigation with saline water in the substrate with organic compost.

The shoot biomass accumulation in plants irrigated with water of $4.5 \mathrm{dS} \mathrm{m}{ }^{-1}$ in the substrate organic compound (Figure 1) is allocated the high amount of nutrients added in the substrate and the carbon dioxide and acid release organic compounds to the soil solution during decomposition, which reduces the percentage of exchangeable sodium (PST) in the substrate to the detriment of the increase in calcium and magnesium (MIRANDA et al. , 2011; SOUZA et al. , 2014). A similar trend was Checked the by Lopes et al. (2017) when evaluating the biomass produced by the aerial part of seedlings of melon cultivars (Cucumis melo L.) irrigated with salinity water up to $4.5 \mathrm{dS} \mathrm{m}^{-1}$. The application of organic compost mitigates the deleterious effects of salts, promoting greater accumulation of biomass and greater photosynthetic efficiency of seedlings (CAVALCANTE et al. , 2016).

The application of organic matter, originating from the organic compound, is beneficial for the formation of root biomass of the Oiticica seedlings (Figure 2), since it contributes to the maintenance and/or improvement of the substrate structure, which promotes greater growth and root exploration, in addition to contributing to greater water storage and availability of nutrients to plants (STEFANOSKI et al., 2013).

The reduction in the relationship between the biomass values of the aerial part/root (Figure 3 ) is possibly an adaptive response of the plant to salt stress, either due to the greater formation of root biomass, which allows the exploration of a larger volume of soil under saline conditions and promotes better absorption of water and nutrients (Sá et al., 2013) or by reducing the biomass production of the aerial part, which avoids the loss of water by evapotranspirative processes, especially by reducing leaf emissions and expanding the area leaf (SYVERTSEN; GARCIA-SANCHEZ, 2014; MUNNS; GILLIHAM, 2015). This trend corroborates the results recorded in corn (Zea mays L.) by Turan et al. (2010), when reporting that the increase in the concentration of sodium chloride in the irrigation water harms the formation of biomass and increases the concentration of toxic elements $(\mathrm{Na}+$ and $\mathrm{Cl}$ -) in the tissues of the plants. According to the authors, the biomass of the aerial part of the seedlings is more affected by salinity than the root system.

These declines in chlorophyll indexes (Figure $4 \mathrm{~A}$ and $\mathrm{C}$ ) are caused by the effects of salt stress in inhibiting leaf area expansion, which is reflected in the reduction of plants in producing chlorophyll due to the production of proteolytic enzymes, such as chlorophyllase, an enzyme of greater expression in the degradation of chlorophyllatic pigments (SANTOS, 2004; KAYA et al., 2010). The reduction in the levels of chlorophyll $a$ and $b$ by the increase in the electrical conductivity of irrigation water has also been recorded in several cultures, among them noni (Morinda citrifolia L.) by Souto et al. (2015), in yellow passion fruit - Passiflora edulis (FREIRE et $a l ., 2013$ ) and even in Oiticica seedlings (DINIZ NETO et al., 2014).

The increase in chlorophyll contents of Oiticica seedlings grown on the substrate with an organic compound (Figure 4B and D) is allocated the action of the organic feedstock in the attenuation of salinity and in increasing fertility (Table 1), besides being rich in organic matter and nutrient, such as nitrogen, phosphorus, potassium, calcium and magnesium, which are essential and play vital roles in the biosynthesis of proteins and photosynthetic pigments in plants (FREIRE et al., 2013; ROSSINI-OLIVA et al., 2017).

The superiority of chlorophyll $a$ over chlorophyll $b$ expresses the elevation of the photosystem II - PSII ratio and the light absorption complex of photosystem II - LHCII, since the PSII photochemical reaction centers are devoid of $\mathrm{Cl} b$ (JINWEN et al., 2009). For Esteban et al. (2015), the relationship between the pigments can be an indicator of the degree of acclimatization of the structures of the photosynthetic system to the light conditions imposed by the environment. In yellow passion fruit leaves, Cavalcante et al. (2011) observed higher values of the chlorophyll $a / b$ ratio in treatments in which organic input was added to the substrate for plant growth.

Chlorophyll is a parameter that is directly correlated with the photosynthetic activity of plants; therefore, the increase in the concentration of salts in levels beyond that tolerated in the chloroplast of the leaves inhibits pigment synthesis, as was seen in Figure 6, and, in this context, the concentration of chlorophyll has been used as one of the indicators of sensitivity and the cellular metabolic activity of plants (SANTOS, 2004; MUNNS; GILLIHAM, 2015 ). Thus, some scientific articles show the attenuating action of organic compounds to the degenerative effects of salts of irrigation water on the chlorophyllate pigments of plants, as observed by Cavalcante et al. (2011) and Freire et al. (2013) in yellow passion fruit, Souza et al. (2014) and Souto et al. (2015) in noni and Diniz et al. (2014) in Oiticica seedlings. 


\section{CONCLUSIONS}

- The addition of organic compost attenuates, but does not eliminate the effects of irrigation water salinity under the accumulation of biomass and the chlorophyllate indices of Oiticica seedlings.

- The salts of the irrigation water hinder the growth of the seedlings, reducing the formation of biomass and leaf photosynthetic pigments.

- The proportion of 1C: 1S is the most suitable, in the substrate, for the production of Oiticica seedlings under conditions of saline water stress.

\section{REFERENCES}

ALVARES, C. A.; STAPE, J. L.; SENTELHAS, P. C.; GONÇALVES, J. L. de M.; SPAROVEK, G. Köppen's climate classification map for Brazil. Meteorologische Zeitschrift, Berlin, v. 22, n. 6, p. 711-728, 2013.

CAVAlCANTE, A. C. P.; DiniZ NETO, M. A.; CAVAlCANTE, L. F.; CAVAlCANTE, A. G. DINIZ, B. L. M. T.; ARAÚJO, R. da C.; MESQUITA, E. F. de; ZUZA, J. F. C. Saline water and organic matter in the development and quality of Licania rigida Benth. seedlings. African Journal of Agricultural Research, Lagos, v. 11, n. 30, p. 2796-2805, 2016.

CAVALCANTE, L. F.; DIAS, T. J.; NASCIMENTO, R. do; FREIRE, J. L. de O. Clorofila e carotenoides em maracujazeiro-amarelo irrigado com águas salinas no solo com biofertilizante bovino. Revista Brasileira de Fruticultura, Jaboticabal, v. especial, p. 699-705, 2011.

DINIZ NETO, M. A.; SILVA, I. de F.; CAVALCANTE, L. F.; DINIZ, B. L. M. T.; SILVA, J. C. A. da; SILVA, E. C da. Mudas de oiticica irrigadas com águas salinas no solo com biofertilizante bovino e potássio. Revista Brasileira de Engenharia Agrícola e Ambiental, Campina Grande, v. 18, n. 1, p. 10-18, 2014.

EMBRAPA - Empresa Brasileira de Pesquisa Agropecuária. Manual de Métodos de Análise do Solo. Brasília: Embrapa Solos, 3 ed. 2017. 573 p.

EMBRAPA. Centro Nacional de Pesquisa de Solos. Sistema Brasileiro de Classificação de Solos. Brasília: Embrapa Solos, 3 ed. 2013. 353 p.

ESTEBAN, R.; BARRUTIA, O.; ARTETXE, U.; FERNÁNDEZ-MARÍN, B.; HERNÁNDEZ, A.; GARCÍAPLAZAOLA, J. I. Internal and external factors affecting photosynthetic pigment composition in plants: a metaanalytical approach. New Phytologist, Cambridge, v. 206, n. 1, p. 268-280, 2015.

FERREIRA, D. F. Sisvar: a Guide for its Bootstrap procedures in multiple comparisons. Ciência e Agrotecnologia, Lavras, v. 38, n. 2, p. 109-112, 2014.

FREIRE, J. L. O.; CAVALCANTE, L. F.; NASCIMENTO, R. do; REBEQUI, A. M. Teores de clorofila e composição mineral foliar do maracujazeiro irrigado com águas salinas e biofertilizante. Revista de Ciências Agrárias, Lisboa, v. 36, n. 1, p. 57-70, 2013.

GORJIN, T.; SERTEL, E.; TANIK, A. Monitoring soil salinity via remote sensing technology under data scarce conditions: A case study from Turkey. Ecological Indicators, Porto, v. 74, n. 1, p. 384-391, 2017.

JINWEN, L.; JINGPING, Y.; PINPIN, F.; JUNLAN, S.; DONGSHENG, L.; CHANGSHUI, G.; WENYUE, C.; Responses of rice leaf thickness, SPAD readings and chlorophyll $\mathrm{a} / \mathrm{b}$ ratios to different nitrogen supply rates in paddy field. Field Crops Research, Amsterdam, v. 114, n. 3, p. 426-432, 2009.

KAYA, C.; TUNA, A. L.; DIKILITAS, M.; CULLU, M. A. Responses of some enzymes and key growth parameters of salt-stressed maize plants to foliar and seed applications of kinetin and indole acetic acid. Journal of Plant Nutrition, New York, v. 33, n. 3, p. 405-422, 2010.

LOPES, M. A. C.; MUNIZ, R. V. da S.; ALVES, S. S. V.; FERREIRA, A. C.; SÁ, F. V. S. da; SILVA, L. de Água salina e substratos no crescimento inicial do meloeiro A. Água salina e substratos no crescimento inicial do meloeiro. Irriga, Botucatu, v. 22, n. 3, p. 469-484, 2017.

MIRANDA, M. A.; OLIVEIRA, E. E. M. de; SANTOS, K. C. F. dos; FREIRE, M. B. G. dos S; ALMEIDA, B. G. de. Condicionadores químicos e orgânicos na recuperação de solo salino-sódico em casa de vegetação. Revista Brasileira de Engenharia Agrícola e Ambiental, Campina Grande, v.15, n. 5, p. 484-490, 2011. 
MUNNS, R.; GILliHAM, M. Salinity tolerance of crops - what is the cost?. New Phytologist, Cambridge, v. 208, n. 3, p. 668-373, 2015.

QUEIROGA, V. P.; BARBOSA, C. R. C.; FIRMINO, P. de T.; ALMEIDA, F. de A. C.; ALBUQUERQUE, E. M. B. de. Oiticica: exploração agronômica e aproveitamento energético. Campina Grande: AREPB, 2 ed. 2016. $175 \mathrm{p}$.

RIBEIRO, M. R.; RIBEIRO FILHO, M. R.; JACOMINE, P. K. T. Origem e classificação dos solos afetados por sais. In: GHEYI, H. R.; DIAS, N. S.; LACERDA, C. F. de; GOMES FILHO, E. Manejo da salinidade na agricultura: estudos básicos e aplicados. Fortaleza: INCTSal, 2016, 504p.

ROSSINI-OLIVA, S.; MINGORANCE, M. D.; PEÑA, A. Effect of two different composts on soil quality and on the growth of various plant species in a polymetallic acidic mine soil. Chemosphere, Oxford, v. 168, n. 1, p. 183$190,2017$.

SÁ, F. V. da S.; BRITO, M. E. B.; MELO, A. S de.; ANTÔNIO NETO, P.; FERNANDES, P. D.; FERREIRA, I. B. Produção de mudas de mamoeiro irrigadas com água salina. Revista Brasileira de Engenharia Agrícola e Ambiental, v. 17, n. 10, p. 1047-1054, 2013.

SANTOS, C. V. Regulation of chlorophyll biosynthesis and degradation by salt stress in sunflower leaves. Scientia Horticulturae, Amsterdam, v. 103, n. 1, p. 93-99, 2004.

SOUTO, A. G. de L.; CAVALCANTE, L. F.; GHEYI, H. R.; NUNES, J. C.; OLIVEIRA, F. I. F. de; ORESCA, D. Photosynthetic pigments and biomass in noni irrigated with saline waters with and without leaching. Revista Brasileira de Engenharia Agrícola e Ambiental, Campina Grande, v. 19, n. 11, 2015.

SOUZA, M. C. M. R. de; LACERDA, C. F. de; AMORIM, A. V.; MENEZES, A. S. Influência da matéria orgânica e do ambiente no crescimento e acúmulo de solutos em Morinda citrifolia submetida à salinidade. Revista Brasileira de Fruticultura, Jaboticabal, v. 36, n. 3, p. 704-712, 2014.

STEFANOSKY, D. C.; SANTOS, G. G.; MARCHÃO, R. L.; PETTER, F. A.; PACHECO, L. P. Uso e manejo do solo e seus impactos sobre a qualidade física. Revista Brasileira de Engenharia Agrícola e Ambiental, Campina Grande, v. 17, n. 12, p. 1301-1309, 2013.

SYVERTSEN, J. P.; GARCIA-SANCHEZ, F. Multiple abiotic stresses occurring with salinity stress in citrus. Environmental and Experimental Botany, Elmsford, v. 103, n. 1, p. 128-137, 2014.

TURAN, M. A.; ELKARIM, A. H. A.; TABAN, N.; TABAN, S. Effect of salt stress on growth and ion distribution and accumulation in shoot and root of maize plant. African Journal of Agricultural Research, Lagos, v. 5, n. 7, p. 584-588, 2010. 